\title{
Using Rubrics for Assessing Student Projects in FAR Part 147 Programs
}

\author{
Lowell W. Berentsen \\ Southern Illinois University Carbondale
}

\begin{abstract}
Most educators in Aviation Maintenance Technology (AMT) programs will agree that the assessment and grading of practical projects in the lab portion of their AMT courses should be as objective as possible. The U.S. Department of Transportation (USDOT) and the Federal Aviation Administration (FAA) have published Advisory Circular (AC) 147-3A, to provide guidance to aviation maintenance technician schools operating under Part 147 of Title 14 of the Code of Federal Regulations (14 CFR), commonly known as the Federal Aviation Regulations (FAR). According to AC 147-3A, in the development of practical projects, objective grading criteria must be used. The challenge for the instructor is to develop practical solutions for the objective grading of projects, and the purpose of this paper is to suggest one such practical solution - the development and use of rubrics.
\end{abstract}

\section{INTRODUCTION}

The activity of completing projects in a Part 147 (Aircraft Maintenance Schools) program is a requirement of the FAA. It is also a requirement that those projects be graded objectively. This can easily become a very subjective task for the instructor. Instructors who have been teaching for a number of years, and also have field experience in the industry, pride themselves in being able to look at a project, determine that the work has been satisfactorily completed in terms of airworthiness, then issue a grade for the project. Has the student really learned, however, how to evaluate his or her own work, or the work of someone else, to determine what makes the project component an airworthy item?

One of the most effective methods of measuring abilities objectively is the use of a well designed rubric. What is a rubric? A rubric may be thought of as a qualitative check list that allows for a precise determination of quality and objective guidelines for assigning a score to a project (UNC/CTL, 2005). Stevens and Levi define a rubric as "a scoring tool that lays out the specific expectations for an assignment," (2005, p. 3). Rubrics have been around for a long time but not all educators have been exposed to the rubric-method of assessment. Rubrics have usually been used to evaluate lab projects, particularly in secondary education settings. Projects, however, are often considered to be nontraditional learning activities by the post secondary academia (UNC/CTL, 2005). Nevertheless, according to Karen Owens, "Rubrics have emerged as evaluation tools that higher education constituents are increasingly exploring" (2006, p. 72).

\section{BACKGROUND}

\section{Meeting the Requirements}

It is interesting to see that higher education academia is recognizing the value in students producing creative and innovative projects in which they are able to put into practice the concepts they have learned in any given course rather than rely only on term papers and written examinations. The staff of the Center for Teaching and Learning at the University of North Carolina (UNC/CTL) has written, "When students are required to exercise judgment and create something new, they must operate on the highest cognitive levels (which, incidentally, are the same levels at which we operate in our professional lives). Often, term papers and similar exercises only approximate some of the important intellectual skills that we expect our students to demonstrate. Of course, paper assignments and tests are usually easier to design, evaluate, and administer than special projects and performance exercises. The assignment of nontraditional projects also requires clearly-defined criteria for evaluation, otherwise grading becomes unacceptably subjective," (UNC/CTL, 2005). 
In the world of academia, high school and post-secondary educators are realizing more the importance of applying theory and headknowledge to real-life situations through the use of projects - a basic understanding that has always been a "given" among the trades educators, "shop" teachers, and industrial technology education instructors. The learning activity of doing hands-on projects lends itself to the broadened pedagogical needs of the student - more specifically, his or her learning style (Bloom, Engelhart, Furst, Hill, \& Krathwohl 1956). The teaching and assessment methods for meeting those needs, however, have to be continually evaluated for reliability and validity (Keiser, Lawrenz, \& Appleton, 2004). It matters not what you know if you cannot transfer the knowledge into a functional, reliable activity.

This concept is not new to the FAA. For decades the FAA has administered testing not only in written form, but also in oral and practical examinations, as directed in section 65.79 of Part 65 of Title 14 of the Code of Federal Regulations (14 CFR): "Each applicant for a mechanic certificate or rating must pass an oral and a practical test on the rating he/she seeks. The tests cover the applicant's basic skill in performing practical projects on the subjects covered by the written test for that rating" (USDOT, FAA, 2007). The student has to be able to answer questions and express himself or herself verbally, and perform project requirements satisfactorily to demonstrate an ability to perform an activity as he or she would while working in the industry - generally that of returning a product to airworthy condition.

What does airworthy condition mean? Although you will not find the term "airworthy" or "airworthiness" in Part 1 (Definitions \& Abbreviations) of 14 CFR, "airworthy" is defined in the Airworthiness Inspector's Handbook, technically known as Order 8300.10, as having two conditions: 1) It must conform to its type design or type certificate, meaning the aircraft, engine, propeller, appliance, or parts thereof, must meet the specifications under which it was designed according to 14 CFR $\S 21.31$, and 2) that it is in a condition for safe flight (USDOT, FAA, 2006). The same terminology is used in $14 \mathrm{CFR} \S 21.183$ (a), for issuing standard airworthiness certificates for aircraft. (USDOT, FAA, 2007).

The required projects assigned to the student during the FAA practical examination are typical of those that the student has to produce during the regular course laboratory periods, which are in conjunction with the course lecture periods. Course curriculum requirements for an approved aircraft maintenance technology school are listed in 14 CFR, Part 147, Appendix B. The FAA also requires a specific "teaching level" for each curriculum requirement listed in Appendix B to Part 147. Those teaching levels listed below are from Appendix A to Part 147 (USDOT, FAA, 2007):

1. Level 1 requires:

a. Knowledge of general principles, but no practical application.

b. No development of manipulative skill.

c. Instruction by lecture, demonstration, and discussion.

2. Level 2 requires:

a. Knowledge of general principles, and limited practical application.

b. Development of sufficient manipulative skill to perform basic operations.

c. Instruction by lecture, demonstration, discussion, and limited practical application.

3. Level 3 requires:

a. Knowledge of general principles, and performance of a high degree of practical application.

b. Development of sufficient manipulative skills to simulate return to service.

c. Instruction by lecture, demonstration, discussion, and a high degree of practical application. [italics added] (USDOT, FAA, 2007, Part 147, Appendix A)

The outline clearly shows that "practical application" progresses from none at level one to a high degree at level three, and "development of manipulative skill" progresses from none at level one to sufficient manipulative skills to simulate return to service at level three [italics added] (USDOT, FAA, 2007, Part 147, Appendix A). Clearly, level 1 instruction can be accomplished through lecture and reading 
assignments, without the completion of lab projects by the students. However, instruction at levels 2 and 3 (especially level 3) would not be practically achievable if it were not for the production and completion of projects in the lab segments of the airframe and powerplant curriculum.

\section{Objectivity in Grading}

Exams covering the lecture material and general knowledge are, for the most part, objective, particularly if they consist of multiple choice, or true/false questions. Not only are these types of exams the most objective, but they are easiest on the instructor for grading, thanks to Scantron technology. There is generally little discussion about the scoring, except in the case of a poorly worded question. The grading of lab projects, on the other hand, inherently invites subjective evaluation. When the students do lab projects and work with their hands, performing their personal manipulative skills, the grading of the projects becomes an opportunity for debates over how perfect the project should be and what the grades should be. Students are sometimes offended by the assigned grade and become defensive of their work and skill. "That's good enough!" and "That will work just fine!" or "I did exactly what you told me to do!" are the phrases the instructor hears while trying to critically evaluate a project for airworthiness and a grade. The expectations of the student are frequently not in line with the expectations of the instructor.

In the final analysis of a project, the instructor has to determine, "Is the product airworthy or un-airworthy?" Is it a "go" or "nogo" item? And if the product is airworthy, how does the instructor assign a grade to the student's work? In real life, airworthiness is generally what it comes down to. There may be other considerations such as how much time is left on a life-limited part, and if it is airworthy now will it continue to be airworthy until the time of the next inspection? However, in this discussion let us stay with simply determining whether or not a part, such as an example of a rigid fluid line, which has been manufactured by a student, meets the criteria of airworthiness as published by accepted or approved aircraft maintenance standards. Is the part worthy of being placed in an aircraft which is going to be flown for an undetermined number of hours? And if so, does the student deserve an " $A$ " simply because the product meets the minimum requirements to be airworthy? As instructors in schools certified by the FAA under 14 CFR Part 147 , we usually need to determine a grade other than just pass or fail, particularly if the course is part of a bachelor degree program.

With more AMT programs moving from trade-school status to bachelor degree programs, students are more focused on their individual grade point averages (GPA). Therefore, it is not enough anymore to know how to properly clean a spark plug so it will function as per design, but "how to accomplish the job to receive an "A"" becomes the primary concern. In fact, in some instances the student is perfectly satisfied knowing that he or she received an " $\mathrm{A}$ " on the project, without regard for whether or not the spark plug even works in a live running engine. That is extreme; however, from the student's reference point it is very frustrating to receive an assignment or project without knowing how the instructor is going to grade the final product (Loveland, 2005). From the instructor's reference point, it becomes very difficult to grade the thirtieth project with the same enthusiasm and critical eye as the first project; even worse if the project grading is carried over to the next lab period, which is likely to be a week later. Consistency, fairness, and objectivity make for a big challenge in grading projects and that's where a careful objective plan needs to be implemented.

\section{FAA Mandates Objective Assessment}

Regarding Part 147 programs, the FAA also has concerns about the subjectivity and objectivity of the assessment of practical projects. From an authoritative standpoint, the FAA requires that the aircraft mechanic or technician applicant meets a level of "basic skill in performing practical projects on the subjects covered by the written test for that rating" (USDOT, FAA, 2005, Section 65.79). How does the instructor know if the student has reached a responsible level of performing a skill? This is often a very subjective task for the instructor, whereas, according to the FAA, it must be an objective assessment. Concerning 
requirements in curriculum development of a Part 147 program, Advisory Circular (AC) 147$3 \mathrm{~A}$ states that the AMT course curriculum developer (in most cases that means the course instructor) "must develop practical projects and objective project grading criteria" [italics added] (USDOT, FAA, 2005, January 18, p. 2). The FAA Airworthiness Inspector's Handbook states that the "curriculum shall include enough detail to evaluate the practical projects for correct teaching level . . . and for performance standards and objective grading criteria" [italics added] (USDOT, FAA, 2006, Vol. 2, p. 187-2).

Consider the example of bending and flaring rigid fluid tubing. 14 CFR Part 147, Appendix B (D) (13), states that the student will "fabricate and install rigid and flexible fluid lines and fittings" to the proficiency of level 3 requirements (USDOT, FAA, 2007). Again, level 3 means that the student must demonstrate knowledge of the general principles of the activity, perform to a high degree the application of that knowledge in a practical way, and develop the manipulative skills that are necessary for simulating a return to service of the product (USDOT, FAA, 2007).

The student needs clear guidelines as to how to achieve the skilled level of proficiency of manufacturing an airworthy fluid line, how to recognize and avoid the pitfalls of producing an inferior product, and how to recognize an airworthy final product before turning it in for a grade. This will help the student to determine what to look for and learn how to evaluate his or her own project and see the progress he or she has made (Loveland, 2005). This cannot be achieved simply by reading charts and viewing figures in manuals and textbooks. Having a "level 3" working knowledge coupled with critical-thinking skills are especially important for the student who is going to be an aircraft technician, as he or she makes decisions daily based upon the judgment of a product as to whether or not it is qualified to be returned to service.

\section{Using Rubrics in AMT Programs}

As already stated, one of the most effective methods of measuring abilities objectively is the use of a well designed rubric. "Rubrics divide an assignment into its component parts and provide a detailed description of what constitutes acceptable or unacceptable levels of performance for each of those parts" (Stevens \& Levi, 2005, p. 3).

So far, in my limited search, I have found no rubrics that adequately represent what we do with aviation maintenance projects. If we choose to use rubrics for assessing student projects we will have to design our own using the criteria that are laid out for us already in the FAA approved and acceptable publications and guidelines, which we use in the industry.

\section{THE ANATOMY AND USE OF A RUBRIC}

An example of a rubric titled "Bending, Flaring, \& Installation of Rigid Aluminum Fluid Lines" has been provided in the appendix. Introduction to Rubrics, by Stevens and Levi, is an excellent source for learning to design specific rubrics. In designing rubrics, Excel by Microsoft is an excellent construction tool, but it can also be done with a simple Microsoft Word or WordPerfect table. The initial attempt to design a rubric for a specific project will require some extra preparation time. However, if the instructor knows the material and possesses the empirical knowledge (i.e., practical experience in the fabrication and flaring of tubing), this should not be a monumental challenge.

\section{Title and Task}

At the top of the example rubric in the appendix, and the partial view in Table 1, you will find the title, "Bending, Flaring, \& Installation of Rigid Aluminum Fluid Lines." Next, the Task Description may be placed under the title of the rubric, which briefly describes what the assignment is about. The purpose of the rubric is not to provide step-by-step instructions to the student. It is to serve the instructor as a qualitative checklist for inspecting the project and determining a grade; however, it does also provide guideline criteria and feedback for the student. The actual instructions are provided separately in the class lecture, in the textbooks, and by the instructor's demonstrations. 
Table 1. Partial view of Rubric in Appendix - Criteria, Scale, and Score

\section{Bending, Flaring, \& Installation of Rigid Aluminum Fluid Lines (Rubric)}

Task Description: Each student will fabricate an airworthy aluminum fluid line with flared ends and AN fittings in accordance with Advisory Circular 43.13-1B, the specifications below, and the instructions from class lectures.

\begin{tabular}{|c|c|c|c|c|c|}
\hline $\begin{array}{c}\text { Criteria } \\
\text { Bends:1-4 } \\
\text { Flares: } 5-11\end{array}$ & $\begin{array}{c}\text { Not a pretty } \\
\text { picture: Zero } \\
\text { Points }\end{array}$ & $\begin{array}{l}\text { Novice: } 75 \% \\
\text { of Total Points }\end{array}$ & $\begin{array}{c}\text { Proficient: } \\
\text { 90\% of Total } \\
\text { Points }\end{array}$ & $\begin{array}{c}\text { Exemplary: } \\
\text { 100\% of Total } \\
\text { Points }\end{array}$ & $\begin{array}{l}\text { Enter } \\
\text { Score }\end{array}$ \\
\hline $\begin{array}{ll}\text { Flattened O.D. of } \\
\text { bend must be at } \\
\text { least } 75 \% \\
\text { original O.D. } \\
\text { points total) } \\
\end{array}$ & $\begin{array}{l}\text { Flattened O.D. is } \\
\text { less than } 75 \% \text { of } \\
\text { the original } \\
\text { diameter of the } \\
\text { tubing. }\end{array}$ & $\begin{array}{l}\text { Not Applicable. } \\
\text { Pass or fail. }\end{array}$ & $\begin{array}{l}\text { Not Applicable. } \\
\text { Pass or fail. }\end{array}$ & $\begin{array}{l}\text { Flattened O.D. is } \\
\text { still at least } 75 \% \text { of } \\
\text { the original } \\
\text { diameter of the } \\
\text { tubing. }\end{array}$ & \\
\hline $\begin{array}{l}\text { All bend radii } \\
\text { within limits. }(5 \\
\text { pts.) }\end{array}$ & $\begin{array}{ll}\text { Does not meet } \\
\text { minimum } \\
\text { radii. }\end{array}$ & $\begin{array}{l}\text { Not Applicable. } \\
\text { Pass or fail. }\end{array}$ & $\begin{array}{l}\text { Not Applicable. } \\
\text { Pass or fail. }\end{array}$ & $\begin{array}{l}\text { Meets minimum } \\
\text { bend radii. }\end{array}$ & \\
\hline $\begin{array}{l}\text { Dents must be } \\
\text { less than } 20 \% \text { of } \\
\text { O.D. of tubing } \\
\text { and not in heel of } \\
\text { bend. ( } 5 \text { pts) }\end{array}$ & $\begin{array}{l}\text { Dent is } 20 \% \text { or } \\
\text { more of outside } \\
\text { diameter of tube or } \\
\text { in the heel of the } \\
\text { bend. }\end{array}$ & $\begin{array}{l}\text { Dents less than } \\
20 \% \text { of the outside } \\
\text { diameter and not } \\
\text { removed. }\end{array}$ & $\begin{array}{l}\text { Dents less than } \\
20 \% \text { of the outside } \\
\text { diameter but } \\
\text { removed with a } \\
\text { "bullet." }\end{array}$ & No dents. & \\
\hline $\begin{array}{l}\text { Tubing free of } \\
\text { tool marks and } \\
\text { damage. } \\
\text { pts.) }\end{array}$ & $\begin{array}{l}\text { Nicks or scratches } \\
\text { in heel of bend. } \\
\text { Twisting, } \\
\text { wrinkling, or } \\
\text { buckling. }\end{array}$ & $\begin{array}{l}\text { Scratches/nicks no } \\
\text { deeper than } 10 \% \text { of } \\
\text { wall thickness. }\end{array}$ & $\begin{array}{l}\text { Scratches/nicks no } \\
\text { deeper than } 10 \% \text { of } \\
\text { wall thickness but } \\
\text { repaired. }\end{array}$ & $\begin{array}{l}\text { No scratches, } \\
\text { nicks, twisting, } \\
\text { wrinkling, buckling } \\
\text { or tool marks. }\end{array}$ & \\
\hline $\begin{array}{l}\text { \#1 Flare width. } \\
(10 \text { pts.) }\end{array}$ & $\begin{array}{l}\text { Too wide or too } \\
\text { narrow. }\end{array}$ & $\begin{array}{l}\text { Minimum width as } \\
\text { per information } \\
\text { provided. }\end{array}$ & $\begin{array}{l}\text { Between minimum } \\
\text { and recommended } \\
\text { width. }\end{array}$ & $\begin{array}{l}\text { Recommended } \\
\text { width. }\end{array}$ & \\
\hline $\begin{array}{l}\text { \#2 Flare width. } \\
\text { (10 pts.) }\end{array}$ & $\begin{array}{l}\text { Too wide or too } \\
\text { narrow. }\end{array}$ & $\begin{array}{l}\text { Minimum width as } \\
\text { per information } \\
\text { provided. }\end{array}$ & $\begin{array}{l}\text { Between minimum } \\
\text { and recommended } \\
\text { width. }\end{array}$ & $\begin{array}{l}\text { Recommended } \\
\text { width. }\end{array}$ & \\
\hline
\end{tabular}

\section{The Criteria}

The column of cells down the left side of the rubric (Table 1) lists the criteria being evaluated on the project. The example rubric in the appendix has a longer list of criteria than what is recommended. Stevens and Levi suggest that one should begin with three to five criteria (2005). Shorter versions of the example could be created by dividing the project into three separate rubrics, one for each part of the assignment.

Included with each criterion are assigned points. The assignment of point value to each criterion, which of course is somewhat subjective, is left to the experience of the instructor, both as an instructor and as a competent aviation maintenance technician in the industry. However, there will be consistency in the grading of individual projects. For the sake of consistency, assign equal value points to each criterion of relative significance, depending upon the required skill level, and have the maximum possible points of each criterion add up to $100 \%$. In the example rubric, 10 points total are awarded for the higher-skill criteria and 5 points each for the lower-skill criteria.

\section{The Scale}

Horizontally across the top row of the rubric table (Table 1) is the scale, in percentage of total points, indicating the range of quality to which each criterion of the project might be performed. The range goes from zero percentage of the points allowed (an unairworthy condition, which is "Not a pretty picture") to $100 \%$ of the points, which indicates that the work done on the tubing is "Exemplary" and has been fabricated according to the best practices of AC $43.13-1 \mathrm{~B}$, which is the publication of the U.S. Department of Transportation (USDOT) and FAA for acceptable methods, techniques, and practices used in aircraft inspections and repairs (USDOT, FAA, 1998). The percentage of the maximum points for each criterion, as indicated in each criterion cell in the left column, is determined by the quality of the work done by the student in relation to the limitations outlined by the 
appropriate maintenance manual or FAA guideline - in this case, AC 43.13-1B - and other training aids and manufacturers' instructions.

Work that meets minimum requirements for airworthiness would be considered "Novice," earning $75 \%$ of the total possible points of a criterion ( $70 \%$ is passing), and "middle-of-theroad" work, earning $90 \%$ of the points, would be "Proficient." The rows under the top row scale uses inspection criteria primarily from the guidelines in FAA Advisory Circular (AC) 43.13-1B, chapter 9 , section 2 , for describing the quality of work for each criterion and aligning appropriately under the scale (USDOT, FAA, 1998).

\section{Levels of Quality}

As stated above, each criterion has an unacceptable limit that causes the project to be totally rejected. The old cliché, "a chain is only as strong as its weakest link," certainly applies here. One un-airworthy criterion renders the product un-airworthy - end of story! If a student has a fluid line with perfect flares but a dent in the heel of a bend, the greatest flares in the world will not make it an airworthy product. The student's next try may have less-thanperfect flares but in every respect be of airworthy quality. Knowing this from the start will help motivate the student to do each step of the assignment with care. Final products seldom result in something better than what was sought after. A clearly defined rubric will help motivate and encourage a student to aim for as perfect a product as he or she is capable of producing.

Interestingly, regarding "perfect flares," information about the quality of the tubing flare itself is very limited in AC 43.13-1B. Also, the most popular text books that deal with the subject differ from each other somewhat in how detailed the criteria should be for an airworthy flare, however they do not contradict each other. Each text contributes a little different light on the subject. The old advisory circular AC 659A, Airframe \& Powerplant Mechanics General Handbook, is still a reliable basic text of standard practices from which the newer text books derive much of their information (USDOT, FAA, 1976).

\section{The Final Step}

The final step in using the rubric would be, of course, tallying the score. The column to the right (Table 1), under "Enter Score," is where the instructor enters the individual scores for each criterion, which is the result of the assessed percentage of the total points assigned to that criterion. In this rubric the score for each criterion would be a zero, or $75 \%, 90 \%$, or $100 \%$ of the number of points assigned to that criterion, that being either five or ten points. For example, criterion 4, Tubing free of tool marks and damage, yields a total of 10 possible points. If the student's tubing has a nick less than $10 \%$ of the wall thickness, but it has been properly repaired, the student would receive $90 \%$ of the 10 possible points, which equals 9 points. A "9" is entered in the cell where criterion 4 row and "Enter Score" column intersect.

When all the criteria on the rubric are completed, the total points under "Enter Score" will be added for a total score of $100 \%$ or less in the bottom right corner of the rubric (Table 2). If any criterion falls under the "Not a pretty picture" column, the task has to be done again until the student produces an airworthy product. If laid out correctly, $100 \%$ of each criterion would total $100,90 \%$ of each criterion will total 90 , and so forth.

Two criteria near the bottom of the rubric (Table 2) are not assigned points but are only an "Accept or Reject" of the project. The tube must be clean of debris and it must past the 2000-psi leak test. No matter how good the line appears, a failure in either of those last two criteria renders the fluid line un-airworthy, therefore results in zero points and a rework of the project.

Notice the last line of the rubric (Table 2) gives the instructions to "total points" and also provides for indicating which "attempt" the student has made on the project. The cell states, "Failure in any criteria requires a rework. A maximum of two reworks is allowed for this project. Each rework will result in a 5-point reduction of the numerical grade of the best attempt. The project grade will be the best of the attempts." The instructor may select to deduct a certain number of points from the final total for each time the project has to be reworked. 
Table 2. Partial View of Rubric in Appendix - "Accept or Reject" and Total Points

\begin{tabular}{|c|c|c|c|c|c|c|}
\hline 10 & $\begin{array}{l}\text { Uniformity of } \\
\text { each flare } \\
\text { contact surface. } \\
\text { (10 pts.) }\end{array}$ & $\begin{array}{l}\text { Distortion of the } \\
\text { flare mating } \\
\text { surface. }\end{array}$ & $\begin{array}{l}\text { Slight difference in } \\
\text { uniformity but } \\
\text { good contact } \\
\text { surface. }\end{array}$ & $\begin{array}{l}\text { Very slight } \\
\text { difference in } \\
\text { uniformity. }\end{array}$ & $\begin{array}{l}\text { Visually uniform } \\
\text { around inside of } \\
\text { flare. }\end{array}$ & \\
\hline 1 & $\begin{array}{l}\text { Bends follow } \\
\text { lines on training } \\
\text { board. Fittings } \\
\text { properly } \\
\text { torqued. (10 pts.) }\end{array}$ & $\begin{array}{l}\text { Line does not } \\
\text { follow indicated } \\
\text { path. Fittings } \\
\text { were not properly } \\
\text { torqued. }\end{array}$ & $\begin{array}{l}\text { Tubing veers out- } \\
\text { side of the path but } \\
\text { follows pattern. }\end{array}$ & $\begin{array}{l}\text { Tubing veers off } \\
\text { center but aligns } \\
\text { with path. }\end{array}$ & $\begin{array}{l}\text { Tubing follows on } \\
\text { center of the } \\
\text { indicated path. } \\
\text { Fittings properly } \\
\text { torqued. }\end{array}$ & \\
\hline & $\begin{array}{l}\text { Flared ends not } \\
\text { under stress } \\
\text { when installed on } \\
\text { training board. } \\
\text { (5 pts.) }\end{array}$ & $\begin{array}{l}\text { With one nut tight, } \\
\text { other flare does } \\
\text { not align with } \\
\text { fitting. }\end{array}$ & $\begin{array}{l}\text { With one nut tight, } \\
\text { other flare needs } \\
\text { tweaking to align. }\end{array}$ & $\begin{array}{l}\text { With one nut tight, } \\
\text { other flare aligns \& } \\
\text { B-nut goes on } \\
\text { easily. }\end{array}$ & $\begin{array}{l}\text { With one nut } \\
\text { tight, other flare } \\
\text { rests on \& inline } \\
\text { with fitting. }\end{array}$ & \\
\hline & \multicolumn{5}{|c|}{ Tube and fittings must be clean, free of foreign material (No points - Accept or Reject). } & (A) (R) \\
\hline & \multicolumn{5}{|c|}{ Leak test one minute, 2000 psi. No seeping/leaking permitted (No points - Accept or Reject). } & (A) (R) \\
\hline & \multicolumn{5}{|c|}{$\begin{array}{l}\text { Total points of criteria } 1 \text { through } 12 \text { for total point grade of project. Attempt \# (1) (2) (3) } \\
\text { Failure in any criteria requires a rework. A maximum of two reworks is allowed for this project. Each } \\
\text { rework will result in a 5-point reduction of the numerical grade of the best attempt. Project grade will be the } \\
\text { best of the attempts. }\end{array}$} & \\
\hline
\end{tabular}

These instructions are at the discretion of the instructor, but there should be an incentive for the student to do as well as possible on the project the first time.

Practicing flares on scrap material before actually beginning the project is certainly reasonable. Any good mechanic in the field, who does not fabricate flared lines on a regular basis, will practice on scrap material before beginning the product that will be installed in an aircraft.

In the same token, when developing a new rubric, it is wise for the instructor to first try it on her or himself, and then try it on a student who has already passed the class. To facilitate the measurement of flare diameters, "go" and "no-go" gauges can be fabricated and used for grading the projects quickly. This too takes some of the student questioning out of the exercise. However, where scratches, gouges, or dents are a concern, a suitable micrometer may have to be used.

\section{Criteria for Bending and Flaring Aluminum Tubing}

The criteria used in the rubric for a lab project needs to align with the standards of the industry and the workplace. The student then has the opportunity to apply the knowledge gained in lecture and use the tools and technology to perform quality maintenance on a particular product (Keiser, Lawrenz, \&
Appleton, 2004). Instructors in an aircraft maintenance program do not share the same freedom that educators from other disciplines have in developing performance criteria. The standards for determining what is acceptable and what is not acceptable in the example of a rigid fluid line has been established by the FAA, and in some cases by the aircraft manufacturer. However, if the aircraft manufacturer doesn't provide the criteria needed, the technician and the instructor must turn to AC 43.13-1B.

Regarding the fabrication and inspection of aviation fluid lines, the FAA has some definite guidelines in chapter 9, section 2 of AC 43.131B (USDOT, FAA, 1998):

1. A small amount of flattening in a bend is acceptable as long as the narrowest outside diameter is not less than $75 \%$ of the original outside diameter.

2. Bend radius for the tubing being used must not be less than the minimum radius as per Table 9-2 of AC 43-13-1B.

3. A dent less than $20 \%$ of the tube diameter is permissible as long as it is not in the heel of the bend.

4. Scratches or nicks cannot be deeper than $10 \%$ of the wall thickness. These are repairable as long as they are not in the heel of the bend.

5. No twisting, wrinkling, or buckling is allowed in the tubing. 
6. Flares are to be made using a 37-degree aviation flare forming tool of the correct size for the tubing being flared.

7. Severe die marks, seams, or splits in the tube are not acceptable.

8. The flare is to be smooth, free of burrs and sharp edges.

9. Any crack or deformity in a flare is not acceptable.

10. All foreign material must be removed from the tubing before installation.

11. The torque used when tightening the fittings when connecting to the pressure test stand must be in accordance with Table 9-2 of AC 43.13-1B.

12. When doing a leak check, no leakage is permitted.

As illustrated in the appendix, most of the above criteria are listed down the left side of the rubric table.

\section{ARE RUBRICS WORTH THE TROUBLE?}

\section{Rubrics are Good for Student Motivation}

Rubrics "provide timely, meaningful feedback for students, and have the potential to become an effective part of the teaching and learning process," helping the students become motivated and independent learners (Steven \& Levi, 2005, p. 17). Rubrics establish consistency in assessing student projects and let the students know "right up front" what is expected in their practical project assignments. Many students enter an aviation maintenance technology program with little or no experience in being a mechanic, much less having a familiarity with airplanes and related technologies. Their introduction to the projects that are required, and which have to be completed to an acceptable level of competency in an AMT program, can sometimes be very overwhelming for the first semester student. However, if a student is given a detailed list of clear expectations for a project while going from point $\mathrm{A}$ to point $\mathrm{B}$, that attitude is more likely to become an I-can-do-that attitude rather than one of overwhelming frustration of not knowing what is good enough for the instructor. Owens writes, "Best practices have surmised that student expectations play an important role in student success" (2006, p. 73).

The rubric encourages the student to examine his or her work critically (Steven \& Levi, 2005). The student doesn't have to hand in a project to the instructor blindly, having no idea how she or he has done until the grade is placed on the lab project assignment. The student can make a self evaluation of the project, using the parameters of the rubric, and asking the appropriate questions: "Does this flare meet the requirements my instructor is looking for?" or more importantly, "the requirements of the industry?" "Is this bend too flat?" "Is this nick too deep?" Corrections can be made based upon the student's decision that the work is not airworthy, rather than upon that of the instructor. Critical thinking in examining a rigid fluid line is as important as constructing an airworthy fluid line. More than likely an aircraft maintenance technician in the field will be inspecting fluid lines for airworthiness more often than he or she will be fabricating one, therefore developing a critical eye and mind for the project assignment should be considered a major part of the student's training and education.

\section{Rubrics are Time-Saving for the Instructor}

There are professors and instructors who have been teaching aircraft maintenance forever and "don't need a so-called rubric." They know what they are looking for in a project and their rubric is in their head. They know how to grade fairly and the students all get an even break. That may or may not be true. Instructors need tools to assess student projects fairly, to encourage students in critical thinking while providing them with useful and constructive feedback, to provide the students with the expectations for an airworthy product. Instructors will also be providing themselves with better teaching methods and techniques (Owens, 2006; Stevens \& Levi, 2005). By using a rubric as a guide in lectures, the instructor can demonstrate to the students what causes the discrepancies in a less-than-perfect flare, and how to avoid them. By directing the students' attention, for example, to criteria 7 and 8 (Table 3 ), the instructor can demonstrate what causes die marks or slippage marks in the flare or tubing, and how to avoid the pitfalls that result 
Table 3. Partial View of Rubric in Appendix - Die Marks and Tool Damage

\begin{tabular}{|c|c|c|c|c|c|c|}
\hline & $\begin{array}{l}\text { \#1 flare O.D. free } \\
\text { from die marks, } \\
\text { splits, or damage. } \\
\text { (10 pts.) }\end{array}$ & $\begin{array}{l}\text { Severe die mark, } \\
\text { split, or seam from } \\
\text { over-tightening or } \\
\text { slip marks from } \\
\text { under-tightening. }\end{array}$ & $\begin{array}{l}\text { Very slight die mark } \\
\text { from flaring tool } \\
\text { and slight indication } \\
\text { of slipping in tool. }\end{array}$ & $\begin{array}{l}\text { Very slight die mark } \\
\text { from flaring tool but } \\
\text { no indication of } \\
\text { slipping in tool. }\end{array}$ & $\begin{array}{l}\text { No die mark or split } \\
\text { in flare, and no } \\
\text { damage or slippage } \\
\text { marks whatsoever. }\end{array}$ & \\
\hline 8 & $\begin{array}{l}\text { \#2 flare O.D. free } \\
\text { from die marks, } \\
\text { splits, or damage. } \\
\text { (10 pts.) }\end{array}$ & $\begin{array}{l}\text { Severe die mark, } \\
\text { split, or seam from } \\
\text { over-tightening or } \\
\text { slip marks from } \\
\text { under-tightening. }\end{array}$ & $\begin{array}{l}\text { Very slight die mark } \\
\text { from flaring tool } \\
\text { and slight indication } \\
\text { of slipping in tool. }\end{array}$ & $\begin{array}{l}\text { Very slight die mark } \\
\text { from flaring tool but } \\
\text { no indication of } \\
\text { slipping in tool. }\end{array}$ & $\begin{array}{l}\text { No die mark or split } \\
\text { in flare, and no } \\
\text { damage or slippage } \\
\text { marks whatsoever. }\end{array}$ & \\
\hline & $\begin{array}{l}\text { Each flare contact } \\
\text { surface and lip edge } \\
\text { for smoothness. (10 } \\
\text { pts. total) }\end{array}$ & $\begin{array}{l}\text { Imbedded particles } \\
\text { in the inside } \\
\text { contact surface or } \\
\text { flare lip has rough } \\
\text { or sharp edge. }\end{array}$ & $\begin{array}{l}\text { Inside contact } \\
\text { surface has } \\
\text { appearance of } \\
\text { "wiping" from the } \\
\text { flaring cone. }\end{array}$ & $\begin{array}{l}\text { Some very minute } \\
\text { lines around the } \\
\text { mating surface. No } \\
\text { significant } \\
\text { rough/sharp lip. }\end{array}$ & $\begin{array}{l}\text { Smooth, polished } \\
\text { mating surface. } \\
\text { Flare lip edge is } \\
\text { smooth with no } \\
\text { rough/sharp edges. }\end{array}$ & \\
\hline 10 & $\begin{array}{l}\text { Uniformity of each } \\
\text { flare contact } \\
\text { surface. (10 pts.) }\end{array}$ & $\begin{array}{l}\text { Distortion of the } \\
\text { flare mating } \\
\text { surface. }\end{array}$ & $\begin{array}{l}\text { Slight difference in } \\
\text { uniformity but good } \\
\text { contact surface. }\end{array}$ & $\begin{array}{l}\text { Very slight } \\
\text { difference in } \\
\text { uniformity. }\end{array}$ & $\begin{array}{l}\text { Visually uniform } \\
\text { around inside of } \\
\text { flare. }\end{array}$ & \\
\hline & $\begin{array}{l}\text { Bends follow lines } \\
\text { on training board. } \\
\text { Fittings properly } \\
\text { torqued. (10 pts.) }\end{array}$ & $\begin{array}{l}\text { Line does not } \\
\text { follow indicated } \\
\text { path. Fittings were } \\
\text { not properly } \\
\text { torqued. }\end{array}$ & $\begin{array}{l}\text { Tubing veers out- } \\
\text { side of the path but } \\
\text { follows pattern. }\end{array}$ & $\begin{array}{l}\text { Tubing veers off } \\
\text { center but aligns } \\
\text { with path. }\end{array}$ & $\begin{array}{l}\text { Tubing follows on } \\
\text { center of the } \\
\text { indicated path. } \\
\text { Fittings properly } \\
\text { torqued. }\end{array}$ & \\
\hline & $\begin{array}{l}\text { Flared ends not } \\
\text { under stress when } \\
\text { installed on training } \\
\text { board. ( } 5 \text { pts.) }\end{array}$ & $\begin{array}{l}\text { With one nut tight, } \\
\text { other flare does not } \\
\text { align with fitting. }\end{array}$ & $\begin{array}{l}\text { With one nut tight, } \\
\text { other flare needs } \\
\text { tweaking to align. }\end{array}$ & $\begin{array}{l}\text { With one nut tight, } \\
\text { other flare aligns \& } \\
\text { B-nut goes on } \\
\text { easily. }\end{array}$ & $\begin{array}{l}\text { With one nut tight, } \\
\text { other flare rests on } \\
\& \text { inline with fitting. }\end{array}$ & \\
\hline & \multicolumn{5}{|c|}{ Tube and fittings must be clean, free of foreign material (No points - Accept or Reject). } & (A) $(\mathrm{R})$ \\
\hline & \multicolumn{5}{|c|}{ Leak test one minute, 2000 psi. No seeping/leaking permitted (No points - Accept or Reject). } & (A) (R) \\
\hline & \multicolumn{5}{|c|}{$\begin{array}{l}\text { Total points of criteria } 1 \text { through } 12 \text { for total point grade of project. Attempt \# (1) (2) (3) } \\
\text { Failure in any criteria requires a rework. A maximum of two reworks is allowed for this project. Each rework will result } \\
\text { in a 5-point reduction of the numerical grade of the best attempt. Project grade will be the best of the attempts. }\end{array}$} & \\
\hline
\end{tabular}

in a lower grade.

\section{Rubrics are Good for the Program}

The rubric offers the objectivity in grading projects that meets the criteria of DOT/FAA Advisory Circular 147-3A: It is worth repeating that the curriculum developer "must also develop practical projects and objective project grading criteria" [italics added] (USDOT, FAA, 2005, January 18, p. 2). In the words of Keiser, Lawrenz, and Appleton of the University of Minnesota, rubrics "assess workplace competencies, technical accuracy, and pedagogical soundness of technical education curricula" (2004, p. 182). It is absolutely necessary, especially in a Part 147 AMT program, that projects and rubrics be "consistent from both industrial and pedagogical perspectives" (Keiser, Lawrenz, \& Appleton, 2004 , p. 190). In what other program can you find criteria such as these more important than where men and women are training to perform maintenance on aircraft - vehicles in which thousands of people entrust their lives daily to the integrity and technical competency of aircraft maintenance technicians? The "success of technical education curricula is not only measured by students' achievement in school, but also through the results of that achievement in the world of work" (Keiser, Lawrenz, \& Appleton, 2004, p. 183).

\section{CONCLUSION AND RECOMMENDATIONS}

Rubrics are good for the student, good for the teacher, and good for the program. "Rubrics save time, provide timely, meaningful feedback for students, and have the potential to become an effective part of the teaching and learning process" (Stevens \& Levi, 2005, p. 17). It would be in the best interest of instructors and students if rubrics and other methods for objective assessment were implemented more frequently in the aviation maintenance technology curricula. Designing rubrics would 
require critical thought and extra time initially, but in the long run rubrics do save time, and relieve the instructor and the student of unnecessary anxiety and debate. As instructors in aircraft maintenance, we should possess curricular goals that are measurable and assessment tools that are objective; "the more explicit the outcomes, the easier it is to determine if students achieve them" (Keiser, Lawrenz, \& Appleton, 2004, p. 184; Finch \& Crunkilton, 1999). As instructors in aircraft maintenance, we must use objective and measurable criteria in the assessment of practical projects in which the student will be expected to be competent in performing in the aviation industry. The design and use of rubrics is just one way that objective can be realized. 


\section{APPENDIX: RUBRIC}

\section{Bending, Flaring, \& Installation of Rigid Aluminum Fluid Lines (Rubric)}

Task Description: Each student will fabricate an airworthy aluminum fluid line with flared ends and AN fittings in accordance with Advisory Circular 43.13-1B, the specifications below, and the instructions from class lectures.

\begin{tabular}{|c|c|c|c|c|c|}
\hline $\begin{array}{c}\text { Criteria } \\
\text { Bends: 1-4 } \\
\text { Flares: } 5-11\end{array}$ & $\begin{array}{l}\text { Not a pretty } \\
\text { picture: Zero } \\
\text { Points }\end{array}$ & $\begin{array}{l}\text { Novice: } 75 \% \\
\text { of Total Points }\end{array}$ & $\begin{array}{c}\text { Proficient: } \\
\text { 90\% of Total } \\
\text { Points }\end{array}$ & $\begin{array}{c}\text { Exemplary: } \\
100 \% \text { of Total } \\
\text { Points }\end{array}$ & $\begin{array}{l}\text { Enter } \\
\text { Score }\end{array}$ \\
\hline $\begin{array}{l}\text { Flattened O.D. of } \\
\text { bend must be at } \\
\text { least } 75 \% \text { of } \\
\text { original O.D. ( } 5 \\
\text { points total) }\end{array}$ & $\begin{array}{l}\text { Flattened O.D. is less } \\
\text { than } 75 \% \text { of the } \\
\text { original diameter of } \\
\text { the tubing. }\end{array}$ & $\begin{array}{l}\text { Not Applicable. Pass } \\
\text { or fail. }\end{array}$ & $\begin{array}{l}\text { Not Applicable. Pass } \\
\text { or fail. }\end{array}$ & $\begin{array}{l}\text { Flattened O.D. is still } \\
\text { at least } 75 \% \text { of the } \\
\text { original diameter of } \\
\text { the tubing. }\end{array}$ & \\
\hline $\begin{array}{l}\text { All bend radii } \\
\text { within limits. (5 } \\
\text { pts.) }\end{array}$ & $\begin{array}{l}\text { Does not meet } \\
\text { minimum bend radii. }\end{array}$ & $\begin{array}{l}\text { Not Applicable. Pass } \\
\text { or fail. }\end{array}$ & $\begin{array}{l}\text { Not Applicable. Pass } \\
\text { or fail. }\end{array}$ & $\begin{array}{l}\text { Meets minimum bend } \\
\text { radii. }\end{array}$ & \\
\hline $\begin{array}{l}\text { Dents must be less } \\
\text { than } 20 \% \text { of } O . D . \text { of } \\
\text { tubing and not in } \\
\text { heel of bend. ( } 5 \text { pts) }\end{array}$ & $\begin{array}{l}\text { Dent is } 20 \% \text { or more } \\
\text { of outside diameter } \\
\text { of tube or in the heel } \\
\text { of the bend. }\end{array}$ & $\begin{array}{l}\text { Dents less than } 20 \% \\
\text { of the outside } \\
\text { diameter and not } \\
\text { removed. }\end{array}$ & $\begin{array}{l}\text { Dents less than } 20 \% \\
\text { of the outside } \\
\text { diameter but removed } \\
\text { with a "bullet." }\end{array}$ & No dents. & \\
\hline $\begin{array}{l}\text { Tubing free of tool } \\
\text { marks and damage. } \\
\text { (10 pts.) }\end{array}$ & $\begin{array}{l}\text { Nicks or scratches in } \\
\text { heel of bend. } \\
\text { Twisting, wrinkling, } \\
\text { or buckling. }\end{array}$ & $\begin{array}{l}\text { Scratches/nicks no } \\
\text { deeper than } 10 \% \text { of } \\
\text { wall thickness. }\end{array}$ & $\begin{array}{l}\text { Scratches/nicks no } \\
\text { deeper than } 10 \% \text { of } \\
\text { wall thickness but } \\
\text { repaired. }\end{array}$ & $\begin{array}{l}\text { No scratches, nicks, } \\
\text { twisting, wrinkling, } \\
\text { buckling or tool } \\
\text { marks. }\end{array}$ & \\
\hline $\begin{array}{l}\text { \#1 Flare width. (10 } \\
\text { pts.) }\end{array}$ & $\begin{array}{l}\text { Too wide or too } \\
\text { narrow. }\end{array}$ & $\begin{array}{l}\text { Minimum width as } \\
\text { per information } \\
\text { provided. }\end{array}$ & $\begin{array}{l}\text { Between minimum } \\
\text { and recommended } \\
\text { width. }\end{array}$ & Recommended width. & \\
\hline $\begin{array}{l}\text { \#2 Flare width. (10 } \\
\text { pts.) }\end{array}$ & $\begin{array}{l}\text { Too wide or too } \\
\text { narrow. }\end{array}$ & $\begin{array}{l}\text { Minimum width as } \\
\text { per information } \\
\text { provided. }\end{array}$ & $\begin{array}{l}\text { Between minimum } \\
\text { and recommended } \\
\text { width. }\end{array}$ & Recommended width. & \\
\hline $\begin{array}{l}\text { \#1 flare O.D. free } \\
\text { from die marks, } \\
\text { splits, or damage. } \\
\text { (10 pts.) }\end{array}$ & $\begin{array}{l}\text { Severe die mark, } \\
\text { split, or seam from } \\
\text { over-tightening or } \\
\text { slip marks from } \\
\text { under-tightening. }\end{array}$ & $\begin{array}{l}\text { Very slight die mark } \\
\text { from flaring tool and } \\
\text { slight indication of } \\
\text { slipping in tool. }\end{array}$ & $\begin{array}{l}\text { Very slight die mark } \\
\text { from flaring tool but } \\
\text { no indication of } \\
\text { slipping in tool. }\end{array}$ & $\begin{array}{l}\text { No die mark or split } \\
\text { in flare, and no } \\
\text { damage or slippage } \\
\text { marks whatsoever. }\end{array}$ & \\
\hline $\begin{array}{l}\text { \#2 flare O.D. free } \\
\text { from die marks, } \\
\text { splits, or damage. } \\
\text { (10 pts.) }\end{array}$ & $\begin{array}{l}\text { Severe die mark, } \\
\text { split, or seam from } \\
\text { over-tightening or } \\
\text { slip marks from } \\
\text { under-tightening. }\end{array}$ & $\begin{array}{l}\text { Very slight die mark } \\
\text { from flaring tool and } \\
\text { slight indication of } \\
\text { slipping in tool. }\end{array}$ & $\begin{array}{l}\text { Very slight die mark } \\
\text { from flaring tool but } \\
\text { no indication of } \\
\text { slipping in tool. }\end{array}$ & $\begin{array}{l}\text { No die mark or split } \\
\text { in flare, and no } \\
\text { damage or slippage } \\
\text { marks whatsoever. }\end{array}$ & \\
\hline $\begin{array}{l}\text { Each flare contact } \\
\text { surface and lip edge } \\
\text { for smoothness. } \\
\text { (10 pts. total) }\end{array}$ & $\begin{array}{l}\text { Imbedded particles } \\
\text { in the inside contact } \\
\text { surface or flare lip } \\
\text { has rough or sharp } \\
\text { edge. }\end{array}$ & $\begin{array}{l}\text { Inside contact surface } \\
\text { has appearance of } \\
\text { "wiping" from the } \\
\text { flaring cone. }\end{array}$ & $\begin{array}{l}\text { Some very minute } \\
\text { lines around the } \\
\text { mating surface. No } \\
\text { significant } \\
\text { rough/sharp lip. }\end{array}$ & $\begin{array}{l}\text { Smooth, polished } \\
\text { mating surface. Flare } \\
\text { lip edge is smooth } \\
\text { with no rough/sharp } \\
\text { edges. }\end{array}$ & \\
\hline $\begin{array}{l}\text { Uniformity of each } \\
\text { flare contact } \\
\text { surface. (10 pts.) }\end{array}$ & $\begin{array}{l}\text { Distortion of the } \\
\text { flare mating surface. }\end{array}$ & $\begin{array}{l}\text { Slight difference in } \\
\text { uniformity but good } \\
\text { contact surface. }\end{array}$ & $\begin{array}{l}\text { Very slight difference } \\
\text { in uniformity. }\end{array}$ & $\begin{array}{l}\text { Visually uniform } \\
\text { around inside of flare. }\end{array}$ & \\
\hline $\begin{array}{l}\text { Bends follow lines } \\
\text { on training board. } \\
\text { Fittings properly } \\
\text { torqued. (10 pts.) }\end{array}$ & $\begin{array}{l}\text { Line does not follow } \\
\text { indicated path. } \\
\text { Fittings were not } \\
\text { properly torqued. }\end{array}$ & $\begin{array}{l}\text { Tubing veers out-side } \\
\text { of the path but } \\
\text { follows pattern. }\end{array}$ & $\begin{array}{l}\text { Tubing veers off } \\
\text { center but aligns with } \\
\text { path. }\end{array}$ & $\begin{array}{l}\text { Tubing follows on } \\
\text { center of the } \\
\text { indicated path. } \\
\text { Fittings properly } \\
\text { torqued. }\end{array}$ & \\
\hline $\begin{array}{l}\text { Flared ends not } \\
\text { under stress when } \\
\text { installed on training } \\
\text { board. (5 pts.) }\end{array}$ & $\begin{array}{l}\text { With one nut tight, } \\
\text { other flare does not } \\
\text { align with fitting. }\end{array}$ & $\begin{array}{l}\text { With one nut tight, } \\
\text { other flare needs } \\
\text { tweaking to align. }\end{array}$ & $\begin{array}{l}\text { With one nut tight, } \\
\text { other flare aligns \& } \\
\text { B-nut goes on easily. }\end{array}$ & $\begin{array}{l}\text { With one nut tight, } \\
\text { other flare rests on \& } \\
\text { inline with fitting. }\end{array}$ & \\
\hline \multicolumn{5}{|c|}{ Tube and fittings must be clean, free of foreign material (No points - Accept or Reject). } & (A) (R) \\
\hline \multicolumn{5}{|c|}{ Leak test one minute, 2000 psi. No seeping/leaking permitted (No points - Accept or Reject). } & (A) (R) \\
\hline \multicolumn{5}{|c|}{$\begin{array}{l}\text { Total points of criteria } 1 \text { through } 12 \text { for total point grade of project. Attempt \# (1) (2) (3) } \\
\text { Failure in any criteria requires a rework. A maximum of two reworks is allowed for this project. Each rework will result } \\
\text { in a 5-point reduction of the numerical grade of the best attempt. Project grade will be the best of the attempts. }\end{array}$} & \\
\hline
\end{tabular}




\section{REFERENCES}

Bloom, B., Englehart, M. Furst, E., Hill, W., \& Krathwohl, D. (1956). Taxonomy of educational objectives: The classification of educational goals. Handbook I: Cognitive domain. New York: Longmans, Green and Co.

Finch, C. R. \& Crunkilton, J. R. (1999). Curriculum development in vocational and technical education: Planning, content, and implementation ( $5^{\text {th }}$ ed.). Needham Heights, MA: Allyn and Bacon.

Keiser, J. C., Lawrenz, F., \& Appleton, J. J. (2004). Technical education curriculum assessment, Journal of Vocational Education Research, 29 (3), 181-194.

Loveland, T. R. (2005). Writing standards-based rubrics for technology education classrooms. The Technology Teacher, 65 (2), 19-22.

Owens, K. R. (2006). [Review of the book Introduction to rubrics: An assessment tool to save grading time, convey effective feedback and promote student learning]. Community College Journal of Research \& Practice, 30 (1), 72-74.

Stevens, D. D., \& Levi, A. J. (2005). Introduction to rubrics: An assessment tool to save grading time, convey effective feedback, and promote student learning. Sterling, VA: Stylus Publishing.

University of North Carolina, Center for Teaching and Learning (UNC/CTL). (2005). Evaluating Student Projects. Retrieved December 23, 2005 from http://ctl.unc.edu/fyc9.html.

U.S. Department of Transportation, Federal Aviation Administration. (2005). Advisory Circular 147-3A: Certification and operation of aviation maintenance technician schools. Washington, DC: U.S. Government Printing Office.

U.S. Department of Transportation, Federal Aviation Administration. (1998). Advisory Circular 43.131B: Acceptable Methods, Techniques, and Practices - Aircraft Inspection and Repair. Washington, DC: U.S. Government Printing Office.

U.S. Department of Transportation, Federal Aviation Administration. (1976). Advisory Circular 65-9A: Airframe \& Powerplant Mechanics General Handbook. Washington, DC: U.S. Government Printing Office.

U.S. Department of Transportation, Federal Aviation Administration. (2006). Airworthiness Inspector's Handbook (Order 8300.10 CHG 23). Washington, DC: U.S. Government Printing Office.

U.S. Department of Transportation, Federal Aviation Administration. (2007). Title 14, Code of federal regulations. Washington, DC: U.S. Government Printing Office. 